\title{
DIRECT ASSESSMENT OF STUDENT OUTCOMES: A SYSTEMATIC APPROACH
}

\author{
Alex Koohang, Macon State College, USA, alex.koohang@maconstate.edu \\ Terry Smith, Macon State College, USA, terry.smith1@maconstate.edu
}

This paper is dedicated to Dr. Gloria Rogers -- a genuine scholar, a brilliant educator, and a cherished colleague who never hesitates to share her knowledge with others --

\begin{abstract}
This paper presents a systematic approach to direct assessment of student learning that is adopted by an Information Technology program accredited by ABET. The focus is on the systematic process for regularly assessing and evaluating the extent to which the direct assessment of the student outcomes are being attained. This paper also describes how the results of the process are being utilized to effect continuous improvement of the program.
\end{abstract}

Keywords: Direct assessment, student outcome, performance indicators, continuous improvement, ABET

\section{INTRODUCTION}

ABET describes assessment as "one or more processes that identify, collect, and prepare data to evaluate the attainment of student outcomes and program educational objectives. Effective assessment uses relevant direct, indirect, quantitative and qualitative measures as appropriate to the outcome or objective being measured." [1]

Rogers [2] defined direct assessment as "the direct examination or observation of student knowledge or skills against measurable learning outcomes." Rogers further asserts that "faculty conduct direct assessments of student learning throughout a course using such techniques as exams, quizzes, demonstrations, and reports. These techniques provide a sampling of what students know and/or can do and provide strong evidence of student learning." [2]

The School of Information Technology at Macon State College in Macon, Georgia, USA, has a Bachelor of Science degree program in Information Technology. This program is accredited by ABET. In August 2011, the faculty engaged in a critical review of its all assessment processes to make certain that the data collection process was done in a systematic manner. In particular, one of the processes focused on generated data from direct evidence that allow evaluation of the student outcomes in a sustainable and continuous process, thus making improvements based on credible and valid evidence. The decision was made to move from a process that was focused on data collection designed to validate an abstract target to an information gathering process that provided meaningful evaluation based on direct measures of student performance.

The purpose of this paper is to describe the new adopted process for regularly assessing and evaluating the extent to which the direct assessment of the student outcomes are being attained for the aforementioned program. Furthermore, through a factual example, this paper illustrates the process of collecting data for the direct assessment of a student outcome and how the results are being utilized to effect continuous improvement of the program.

\section{THE PROCESS}

The process of regularly assessing and evaluating the direct assessment of the student outcomes entailed a systematic approach that included 1) fine-tuning the student outcomes; 2) defining high-level performance indicators; 3) establishing strategies; 4) identifying sources of assessment for each student outcome; 5) establishing targets for performance; 6) designing the assessment methods/instruments; 7) developing the rubrics; and 8) developing a systematic data collection process. 


\section{Issues in Information Systems}

Volume 13, Issue 2, pp. 1-10, 2012

The process began with fine-tuning a few student outcomes for clarity and better readability. The ten student outcomes are: 1) identify and apply current technical concepts in the core information technologies; 2) define, analyze, and apply information system requirements in local and global environments; 3) design, implement, and administer effective IT solutions based on user needs; 4 ) demonstrate and use appropriate project management methods in the creation of an effective IT project plan; 5) describe and apply best practices and standards in IT applications; 6) identify and apply IT methods used to protect the confidentiality, integrity, and availability of information and its delivery systems; 7) identify and incorporate relevant ethical, legal, security, and social issues in a technology environment; 8) work effectively in teams to develop IT based solutions; 9) communicate effectively both orally and in writing; and 10) recognize the need for lifelong professional development. This was followed by defining high-level performance indicators for each student outcome. Performance indicators are measurable statements that indicate the specific characteristics students should exhibit in order to demonstrate desired attainment of the student outcomes [3]. Each student outcome was determined to have a minimum of two and a maximum of four performance indicators. Next, strategies were established. This process is the mapping of the courses designed to provide opportunities for students to learn, practice, demonstrate and/or get feedback on their performance on the performance indicators. Strategies identify how the curriculum is aligned with the performance indicators. During this process the source of assessment was determined. The source of assessment for each student outcome is a summative course where the data would be collected. A summative course is the course where student learning is demonstrated at the highest level for each performance indicator. Although there may be more than one summative course, the faculty chose the one course where the students had a significant opportunity to demonstrate their competence related to the outcome. See Table 1 for mapping of the core courses (ITEC 2215, ITEC 2260, ITEC 2270, ITEC 2380, ITEC 3155, ITEC 3225, ITEC 3236, ITEC 3245, ITEC 3280, ITEC 3300, ITEC 3310, ITEC 4200, ITEC 4205, \& ITEC 4750) to the performance indicators and source of assessment for each student outcome.

\begin{tabular}{|c|c|c|c|c|c|c|c|c|c|c|c|c|c|c|c|}
\hline \multicolumn{16}{|c|}{ Table 1: Mapping of Courses } \\
\hline Student Outcomes & 2215 & 2260 & 2270 & 2320 & 2380 & 3155 & 3235 & 3236 & 3245 & 3280 & 3300 & 3310 & 4200 & 4205 & 4750 \\
\hline 1. Crrent technical concepts & $\mathrm{x}$ & $\mathrm{x}$ & $\mathrm{x}$ & $\mathrm{x}$ & $\mathrm{x}$ & $\mathrm{x}$ & $\mathrm{x}$ & $\mathrm{x}$ & $\mathrm{x}$ & $\mathrm{x}$ & $\mathrm{x}$ & $\mathrm{x}$ & $\mathrm{x}$ & $\mathrm{x}$ & $\mathrm{x}$ \\
\hline 2. IS requirements & & & & $\mathrm{x}$ & $\mathrm{x}$ & $\mathrm{x}$ & $\mathrm{x}$ & & $\mathrm{x}$ & $\mathrm{x}$ & $\mathrm{x}$ & $\mathrm{x}$ & $\mathrm{x}$ & & $\mathrm{x}$ \\
\hline 3. IT solution - user needs & & $\mathrm{x}$ & $\mathrm{x}$ & $\mathrm{x}$ & $\mathrm{x}$ & $\mathrm{x}$ & $\mathrm{x}$ & $\mathrm{x}$ & $\mathrm{x}$ & $\mathrm{x}$ & $\mathrm{x}$ & & & & $\mathrm{x}$ \\
\hline 4. Project Management & & & & & & $\mathrm{x}$ & & & & & $\mathrm{x}$ & & & & $\mathrm{x}$ \\
\hline 5. Best practices & & $\mathrm{x}$ & $\mathrm{x}$ & $\mathrm{x}$ & $\mathrm{x}$ & $\mathrm{x}$ & $\mathrm{x}$ & $\mathrm{x}$ & $\mathrm{x}$ & $\mathrm{x}$ & $\mathrm{x}$ & $\mathrm{x}$ & $\mathrm{x}$ & & $\mathrm{x}$ \\
\hline 6. Confidentiality, integrity & & & & $\mathrm{x}$ & & $\mathrm{x}$ & & & $\mathrm{x}$ & & & $\mathrm{x}$ & $\mathrm{x}$ & $\mathrm{x}$ & $\mathrm{x}$ \\
\hline 7. Ehical, legal & $\mathrm{x}$ & & & & $\mathrm{x}$ & & $\mathrm{x}$ & & $\mathrm{x}$ & $\mathrm{x}$ & & $\mathrm{x}$ & $\mathrm{x}$ & $\mathrm{x}$ & $\mathrm{x}$ \\
\hline 8. Work in teams & & & & & & $\mathrm{x}$ & $\mathrm{x}$ & & & & $\mathrm{x}$ & $\mathrm{x}$ & & & $\mathrm{x}$ \\
\hline 9. Communication & & & & & & $\mathrm{x}$ & $\mathrm{x}$ & & & & & $\mathrm{x}$ & & & $\mathrm{x}$ \\
\hline 10. Lifelong learning & $\mathrm{x}$ & & & & & & & & & & $\mathrm{x}$ & $\mathrm{x}$ & $\mathrm{x}$ & & $\mathrm{x}$ \\
\hline
\end{tabular}

$X$ in each cell $=$ the course map to the performance indicators, Solid cell $=$ the Source of Assessment

Subsequently, the target for performance for each performance indicator was determined. If the target for performance for a given performance indicator was set to be $85 \%$, then the success rate of the population should be at $85 \%$ or above. In setting a target for a performance indicator, attention was given to 1) the cognitive level - i.e., knowledge, comprehension, application, analysis, synthesis, evaluation, and 2) curriculum support -the more courses that support student performance for each indicator, the more likely it is that students will achieve the anticipated performance. Table 2 includes examples of three student outcomes, each showing its performance indicators, source of assessment, and target for performance.

The assessment instrument for each student outcome was designed next. The assessment instrument is used to assess student learning. A common assessment for each student outcome was developed to measure its performance indicators. Based on the assessment instrument for each student outcome, the associated rubric was designed to assess student performance. A rubric is an explicit set of criteria used for assessing a particular type of work or performance. A rubric usually includes levels of potential achievement for each criterion, which are often given 


\section{Issues in Information Systems}

Volume 13, Issue 2, pp. 1-10, 2012

numerical scores [4]. For each performance indicator, student performance is scored in the following four categories: 1) unsatisfactory $=$ description of identifiable performance characteristics reflecting a beginning level of performance, 2) developing = description of identifiable performance characteristics reflecting development and movement toward mastery of performance, 3 ) satisfactory $=$ description of identifiable performance characteristics reflecting mastery of performance, and 4) exemplary $=$ description of identifiable performance characteristics reflecting the highest level of performance. [4]

Table 2: Examples of Student Outcomes with their Performance Indicators Student Outcome: Design, implement, and administer effective IT solutions based on user needs. Performance Indicators:

1. Design an effective IT solution based on user requirements

2. Implement and administer an effective IT solution based on user requirements

Source of Assessment (ITEC 3245) Target for Performance for all Performance Indicators (80\%)

Student Outcome: Recognize the need for lifelong professional development

Performance Indicators:

1. Identify the importance of professional development

2. Analyze the different avenues for professional development

3. Create a plan to achieve professional development

Source of Assessment (ITEC 3310) Target for Performance for all Performance Indicators (85\%)

Student Outcome: Identify and apply current technical concepts in the core information technologies.

Performance Indicators:

1. Analyze an information system

2. Design \& develop an Information System

3. Implement an Information System

4. Evaluate an information system

Source of Assessment (ITEC 4750) Target for Performance for all Performance Indicators (85\%)

To reduce the unnecessary workload on faculty and to enable the program to focus on the evaluation and continuous improvement of outcomes in an efficient and sustainable way, a systematic data collection process based on a twoyear cycle was designed. (See Table 3) It was determined that data collection will focus on validating an information gathering process that provided meaningful evaluation based on direct measures of student performance. In other words, data alone cannot drive improvement. Improvement results from information. This is demonstrated in the results section of the factual example.

Table 3: Data Collection Cycle

\begin{tabular}{|l|l|l|l|l|l|l|l|c|}
\hline \multirow{2}{*}{ Student Outcomes } & 2012 & 2013 & 2013 & 2014 & 2014 & 2015 & 2015 & 2016 \\
\hline & Fall & Spring & Fall & Spring & Fall & Spring & Fall & Spring \\
\hline 1. Current technical concepts & $\mathrm{X}$ & & & & $\mathrm{X}$ & & & \\
\hline 2. IS requirements & $\mathrm{X}$ & & & & $\mathrm{X}$ & & & \\
\hline 3. IT solution - user needs & & $\mathrm{X}$ & & & & $\mathrm{X}$ & & \\
\hline 4. Project management & & $\mathrm{X}$ & & & & $\mathrm{X}$ & & \\
\hline 5. Best practices & & $\mathrm{X}$ & & & & $\mathrm{X}$ & & \\
\hline 6. Confidentiality, integrity & & & $\mathrm{X}$ & & & & $\mathrm{X}$ & \\
\hline 7. Ethical, legal & & & $\mathrm{X}$ & & & & $\mathrm{X}$ & \\
\hline 8. Work in teams & & & & $\mathrm{X}$ & & & & $\mathrm{X}$ \\
\hline 9. Communication & & & $\mathrm{X}$ & & & & $\mathrm{X}$ \\
\hline 10. Lifelong learning & & & & $\mathrm{X}$ & & & & $\mathrm{X}$ \\
\hline
\end{tabular}




\section{Issues in Information Systems}

Volume 13, Issue 2, pp. 1-10, 2012

As a part of the systematic data collection process, an assessment packet for direct assessment of each student outcome was developed to include the following information: 1) The student outcome assessment matrix, 2) A description of the assessment instrument, 3) The rubric, 4) Detailed results of the assessment, and 5) The recommended actions for improvement The purpose of the assessment packet is to organize, manage, and store information for each student outcome.

In the next section a factual example of the direct assessment of one student outcome is presented.

\section{A FACTUAL EXAMPLE}

This section presents a factual example of the direct assessment of one student outcome from the aforementioned IT program - "Use appropriate PM methods in the creation of an effective IT project plan". The process of collecting data for this student outcome is reflected in the student outcome's Direct Assessment of Student Outcome Packet. It includes information on the student outcome assessment matrix; a description of the assessment instrument; the detailed rubric; a detailed description of the results; and the recommended actions for improvement.

\section{The Student Outcome Assessment Matrix}

The student outcome assessment matrix is a recap of important information about the assessment of the student outcome. The matrix includes information about the student outcome, performance indicators, strategies, assessment method(s) - what the assessment entails, target for performance, source of assessment, and responsible person(s) for evaluation of results. The matrix is shown below.

\begin{tabular}{|c|c|c|c|c|c|}
\hline \multicolumn{6}{|c|}{$\begin{array}{l}\text { Student Outcome: Use appropriate PM methods in the creation of an effective IT project plan } \\
\text { Semester/Year Data Collected: } \underline{\text { Fall } 2011} \\
\text { Assessment Coordinator: }\end{array}$} \\
\hline Performance Indicators & Strategies & $\begin{array}{c}\text { Assessment } \\
\text { Method(s) }\end{array}$ & $\begin{array}{c}\text { Target for } \\
\text { Performance }\end{array}$ & $\begin{array}{c}\text { Source of } \\
\text { Assessment }\end{array}$ & $\begin{array}{c}\text { Evaluation of } \\
\text { Results }\end{array}$ \\
\hline $\begin{array}{l}\# 1 \\
\text { Apply knowledge of the nine } \\
\text { knowledge areas in project } \\
\text { management (integration, } \\
\text { scope, time, cost, quality, risk, } \\
\text { communication, human } \\
\text { resources, and procurement) } \\
\text { in the creation of an effective } \\
\text { IT project plan }\end{array}$ & $\begin{array}{l}\text { ITEC3155 } \\
\text { ITEC3300 } \\
\text { ITEC4750 }\end{array}$ & $\begin{array}{l}\text { Develop a } \\
\text { Project } \\
\text { Plan }\end{array}$ & $80 \%$ & 3300 & $\begin{array}{l}\text { School of IT's } \\
\text { Curriculum } \\
\text { Committee } \\
\text { ABET Coordinator }\end{array}$ \\
\hline $\begin{array}{l}\# 2 \\
\text { Apply knowledge of the five } \\
\text { project management processes } \\
\text { (initiation, planning, } \\
\text { executing, controlling and } \\
\text { monitoring, and closing) in } \\
\text { the creation of an effective IT } \\
\text { project plan }\end{array}$ & $\begin{array}{l}\text { ITEC3155 } \\
\text { ITEC3300 } \\
\text { ITEC4750 }\end{array}$ & $\begin{array}{l}\text { Develop a } \\
\text { Project } \\
\text { Plan }\end{array}$ & $80 \%$ & 3300 & $\begin{array}{l}\text { School of IT's } \\
\text { Curriculum } \\
\text { Committee } \\
\text { ABET Coordinator }\end{array}$ \\
\hline
\end{tabular}

\section{Assessment Instrument}

The assessment instrument is used to assess student learning. The assessment instrument for the student outcome "Use appropriate PM methods in the creation of an effective IT project plan" is as follows: 


\section{Issues in Information Systems}

Volume 13, Issue 2, pp. 1-10, 2012

"The class is divided into teams and the teams will each be given the responsibility to develop a part of a project plan that will be used to implement an Enterprise Resource Planning (ERP) system. The parts of the system implementation can be as follows: accounts payables, accounts receivable, general ledger, procurement, and IT infrastructure. The plans will address the application of the nine knowledge areas and the five project management processes. The tasks will be defined with dependencies determined and entered. Resources will be assigned to each task."

\section{The Rubric}

The rubric that is used to assess student achievement toward each performance indicator for the student outcome "Use appropriate PM methods in the creation of an effective IT project plan" is shown below:

\begin{tabular}{|c|c|c|c|c|}
\hline Performance Indicators & 1 - Unsatisfactory & 2 - Developing & 3 - Satisfactory & 4 - Exemplary \\
\hline $\begin{array}{l}\text { 1.Apply the nine knowledge } \\
\text { areas in project management } \\
\text { (integration, scope, time, cost, } \\
\text { quality, risk, communication, } \\
\text { human resources, and } \\
\text { procurement) in the creation of } \\
\text { an effective IT project plan. }\end{array}$ & 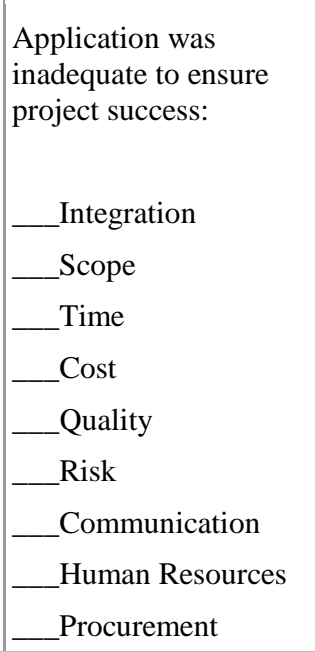 & $\begin{array}{l}\text { Application detail was } \\
\text { minimal to ensure } \\
\text { project success: } \\
\text { Integration } \\
\text { Scope } \\
\text { Time } \\
\text { Cost } \\
\text { Quality } \\
\text { Risk } \\
\text { Communication } \\
\text { Human Resources } \\
\text { Procurement }\end{array}$ & $\begin{array}{l}\begin{array}{l}\text { Application was } \\
\text { adequate to ensure } \\
\text { project success: }\end{array} \\
\text { Integration } \\
\text { Scope } \\
\text { Time } \\
\text { C Cost } \\
\text { Quality } \\
\text { Risk } \\
\text { Communication } \\
\text { H Human Resources } \\
\text { Procurement }\end{array}$ & 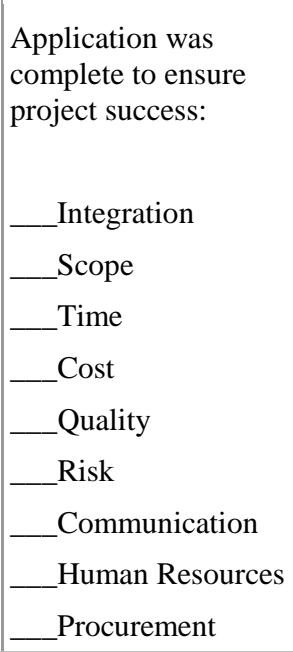 \\
\hline $\begin{array}{l}\text { 2.Apply the five project } \\
\text { management processes } \\
\text { (initiation, planning, executing, } \\
\text { controlling and monitoring, and } \\
\text { closing) in the creation of an } \\
\text { effective IT project plan. }\end{array}$ & $\begin{array}{l}\text { Process was inadequate } \\
\text { to ensure project } \\
\text { success: } \\
\text { Initiation } \\
\text { __Planning } \\
\text { _Execution } \\
\text { Controlling and } \\
\text { monitoring } \\
\text { Closing }\end{array}$ & $\begin{array}{l}\begin{array}{l}\text { Process detail was } \\
\text { minimal to ensure } \\
\text { project success: }\end{array} \\
\text { Initiation } \\
\text { Planning } \\
\text { Execution } \\
\text { Controlling and } \\
\text { monitoring } \\
\text { Closing }\end{array}$ & $\begin{array}{l}\text { Process was adequate } \\
\text { to ensure project } \\
\text { success: } \\
\text { Initiation } \\
\text { Planning } \\
\text { Execution } \\
\text { Controlling and } \\
\text { monitoring } \\
\text { Closing }\end{array}$ & $\begin{array}{l}\begin{array}{l}\text { Process was complete } \\
\text { to ensure project } \\
\text { success: }\end{array} \\
\text { Initiation } \\
\text { Planning } \\
\text { Execution } \\
\text { Controlling and } \\
\text { monitoring } \\
\text { Closing }\end{array}$ \\
\hline
\end{tabular}

\section{Results for Overall Performance Indicators - Data}

The target performance for the two PIs for the student outcome "Use appropriate PM methods in the creation of an effective IT project plan" were set at $80 \%$. This means that $80 \%$ of the students would score "satisfactory" and/ or "exemplary" . Figure 1 shows the performance score for each PI. The sample population $(\mathrm{N}=46)$ represented 


\section{Issues in Information Systems}

Volume 13, Issue 2, pp. 1-10, 2012

students enrolled in ITEC 3300, the Source of Assessment, for this student outcome. The faculty agreed that the sample data obtained using this summative course adequately represented the student population in the program. As can be seen the overall performance score for PI \#1 (apply knowledge of the nine knowledge areas in project management - 1) integration, 2)scope, 3) time, 4) cost, 5) quality, 6) risk, 7) communication, 8) human resources, and 9) procurement - in the creation of an effective IT project plan ) was $86 \%$. This means that $86 \%$ of students scored "satisfactory" and/or "exemplary". Furthermore, the overall performance score for PI \#2 (apply knowledge of the five project management processes - 1) initiation, 2) planning, 3) executing, 4) controlling \& monitoring, and 5) closing - in the creation of an effective IT project plan) was $85 \%$. This means that $85 \%$ of students scored "satisfactory" and/or "exemplary".

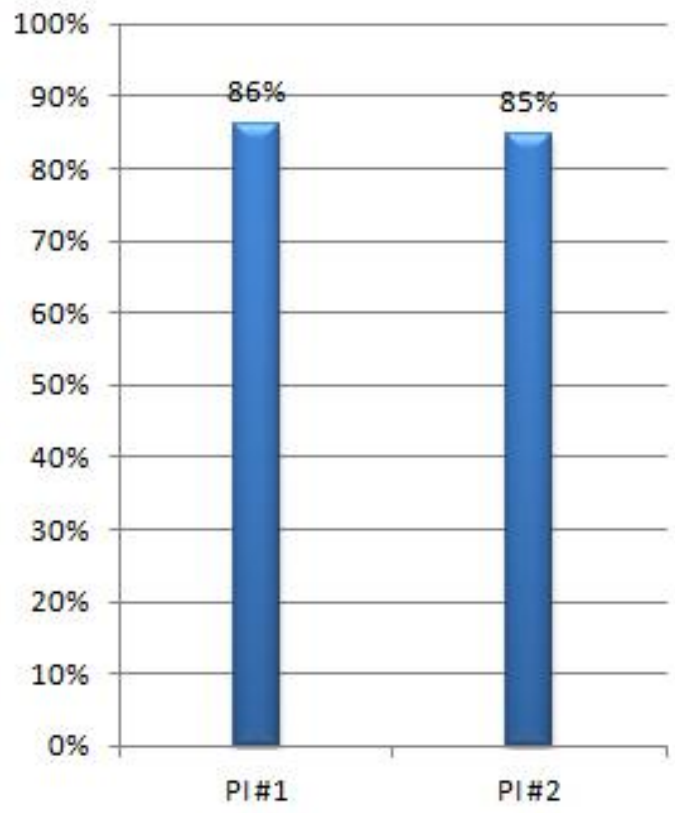

Figure 1: Presentation of Data for the two Performance Indicators

It would appear from the overall average that target performance for each PI (86\% and $85 \%$ respectively) has been met. Nevertheless, what one sees in Figure 1 is merely data - an abstract presentation of the results. Data do not assist in driving improvement. To drive any improvement, one needs information - a detailed presentation of the results.

\section{Results for Performance Indicator \#1 - Information for Driving Improvement}

Figure 2 shows the level 1 presentation of information for PI \#1. Recall that PI \#1 had 9 knowledge areas. The results of performance score for each knowledge area is as follows: (1) integration $=98 \%, 2)$ scope $=98 \%, 3)$ time $=89 \%, 4)$ cost $=54 \%, 5)$ quality $=83 \%, 6)$ risk $=98 \%, 7)$ communication $=78 \%$, 8) human resources $=89 \%$, and 9) procurement $=89 \%$. This information reveals that 7 of the 9 knowledge areas met the target performance of $80 \%$. However, two knowledge areas, cost and communication, did not meet the target performance of $80 \%$. This information reveals that the knowledge areas of cost and communication require improvement.

Figure 3 shows the drilling down of the level 1 presentation of information for each knowledge area based on "exemplary", "satisfactory", "developing", and "unsatisfactory". This is level 2 presentation of information, which further examines where improvement is needed in the knowledge areas that did not meet the target for performance. The level 2 presentation of information scores for the 9 knowledge areas of PI \#1 are shown in Table 4. 


\section{Issues in Information Systems}

Volume 13, Issue 2, pp. 1-10, 2012

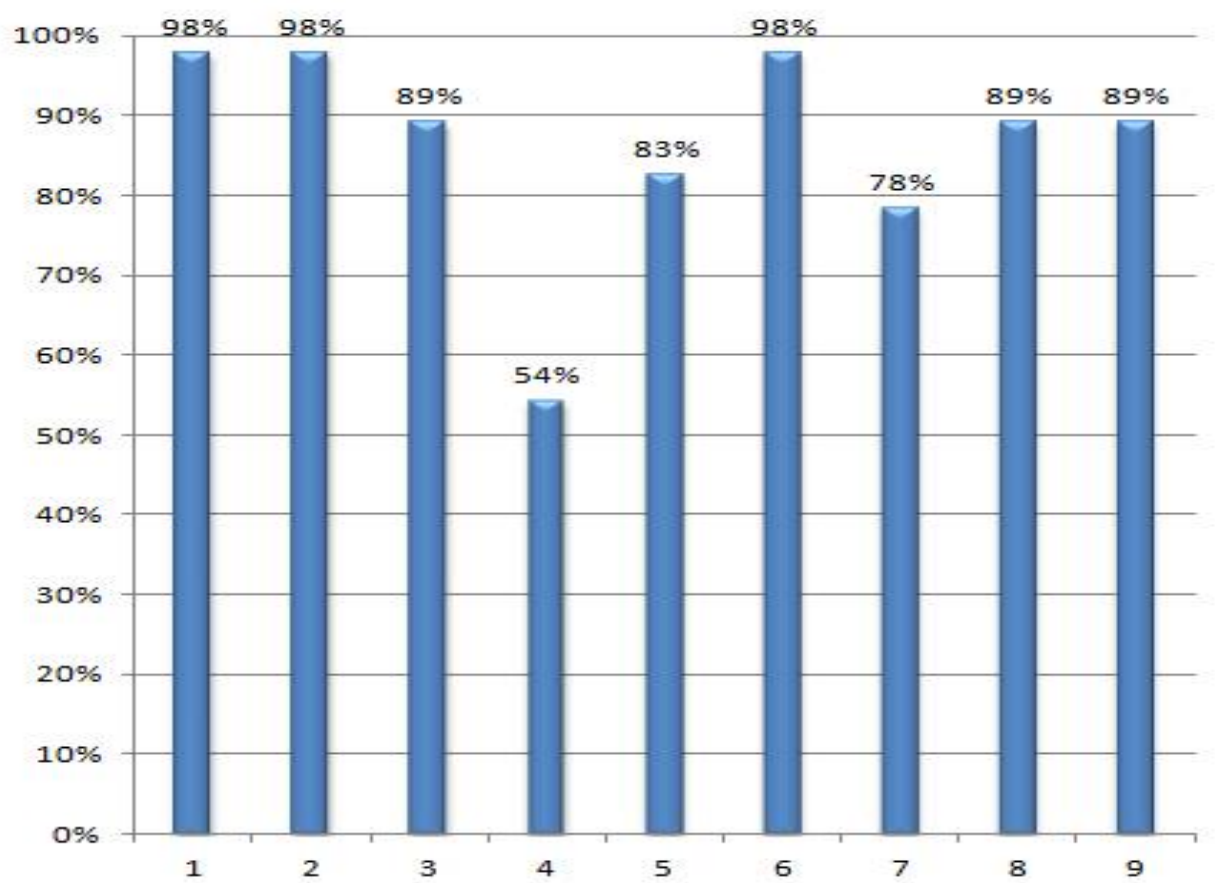

Figure 2: Presentation of Information for PI \#1 - Nine Knowledge Areas - Level 1

1) integration, 2)scope, 3) time, 4) cost, 5) quality, 6) risk, 7) communication, 8) human resources, and 9) procurement

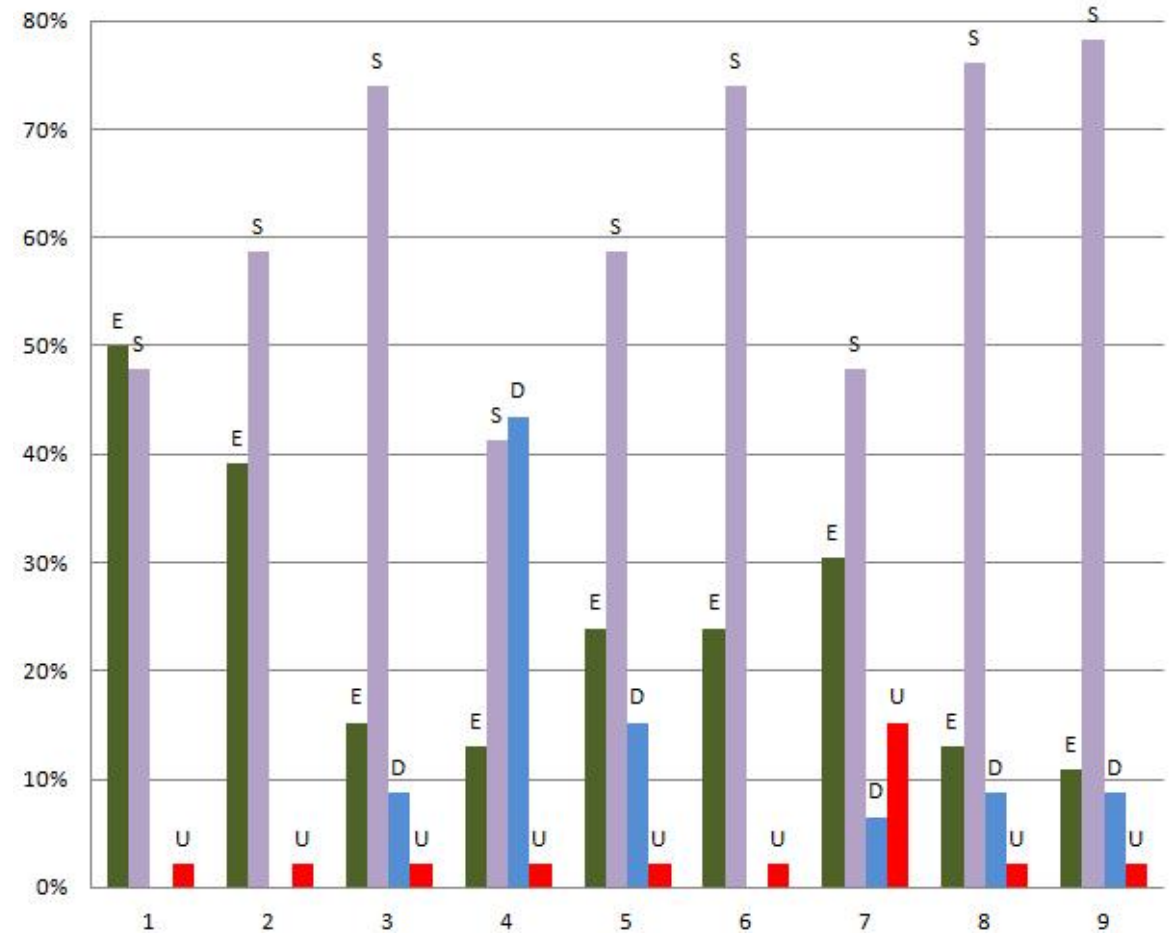

Figure 3: Presentation of Information for PI \#1 - Nine Knowledge Areas - Level 2

1) integration, 2)scope, 3) time, 4) cost, 5) quality, 6) risk, 7) communication, 8) human resources, and 9) procurement $E=$ Exemplary, $S=$ Satisfactory, $D=$ Developing, $U=$ Unsatisfactory 


\section{Issues in Information Systems}

Volume 13, Issue 2, pp. 1-10, 2012

Table 4: The Scores for Level 2 Presentation of Information

\begin{tabular}{|l|r|r|r|r|r|r|r|r|r|}
\hline & 1 & 2 & 3 & 4 & 5 & 6 & 7 & 8 & 9 \\
\hline Exemplary & $50 \%$ & $39 \%$ & $15 \%$ & $13 \%$ & $24 \%$ & $24 \%$ & $30 \%$ & $13 \%$ & $11 \%$ \\
\hline Satisfactory & $48 \%$ & $59 \%$ & $74 \%$ & $41 \%$ & $59 \%$ & $74 \%$ & $48 \%$ & $76 \%$ & $78 \%$ \\
\hline Developing & $0 \%$ & $0 \%$ & $9 \%$ & $43 \%$ & $15 \%$ & $0 \%$ & $7 \%$ & $9 \%$ & $9 \%$ \\
\hline Unsatisfactory & $2 \%$ & $2 \%$ & $2 \%$ & $2 \%$ & $2 \%$ & $2 \%$ & $15 \%$ & $2 \%$ & $2 \%$ \\
\hline
\end{tabular}

1) integration, 2)scope, 3) time, 4) cost, 5) quality, 6) risk, 7) communication, 8) human resources, and 9) procurement

As can be seen in Table 4, in the knowledge area of cost, for example, students scored $54 \%$ (satisfactory $=41 \%$ and exemplary $=13 \%$ ). This knowledge area did not meet the target performance of $80 \%$, therefore, improvement is needed. Looking at the developing score of $43 \%$ in this knowledge area, one can clearly see that measures ought to be taken to advance the developing area to the satisfactory and/or the exemplary areas. Likewise, looking at the information for knowledge area of communication, measures ought to be taken to advance the unsatisfactory area to the developing, the satisfactory, and/or the exemplary areas.

\section{Results for Performance Indicator \#2 - Information for Driving Improvement}

Figure 4 shows the level 1 presentation of information for PI \#2. Recall that PI \#2 had 5 five project management processes. The results of performance score for each process is as follows: 1 ) initiation $=91 \%, 2$ ) planning $=74,3$ ) executing $=91,4)$ controlling \& monitoring $=76 \%$, and 5) closing $=91 \%$. This information shows that 2 of the 5 project management processes for this performance indicator, planning and controlling \& monitoring, did not meet the target performance of $80 \%$. This information reveals that the project management process of planning and controlling \& monitoring requires improvement.

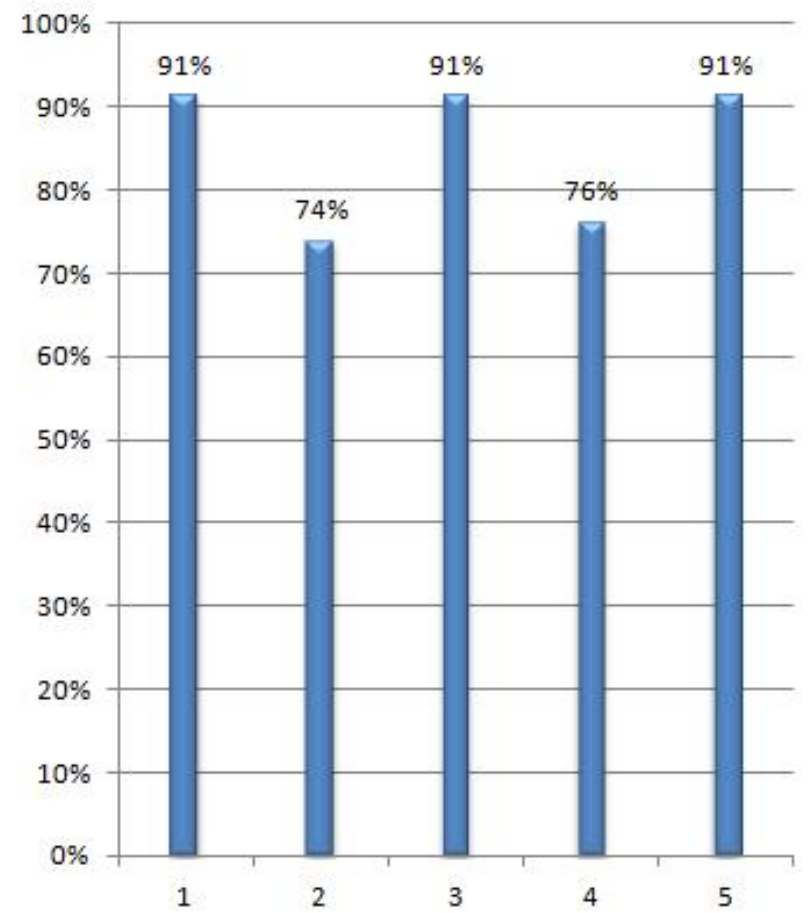

Figure 4: Presentation of Information for PI \#2 - Five Processes - Level 1 1) initiation, 2) planning, 3) executing, 4) controlling \& monitoring, and 5) closing 


\section{Issues in Information Systems}

Volume 13, Issue 2, pp. 1-10, 2012

Figure 5 shows the drilling down of the level 1 presentation of information for each project management processes based on "exemplary", "satisfactory", "developing", and "unsatisfactory". This is level 2 presentation of information, which further examines where improvement is needed in project management processes that did not meet the target for performance. The level 2 presentation of information scores for the five project management processes of PI \#2 are shown in Table 5.

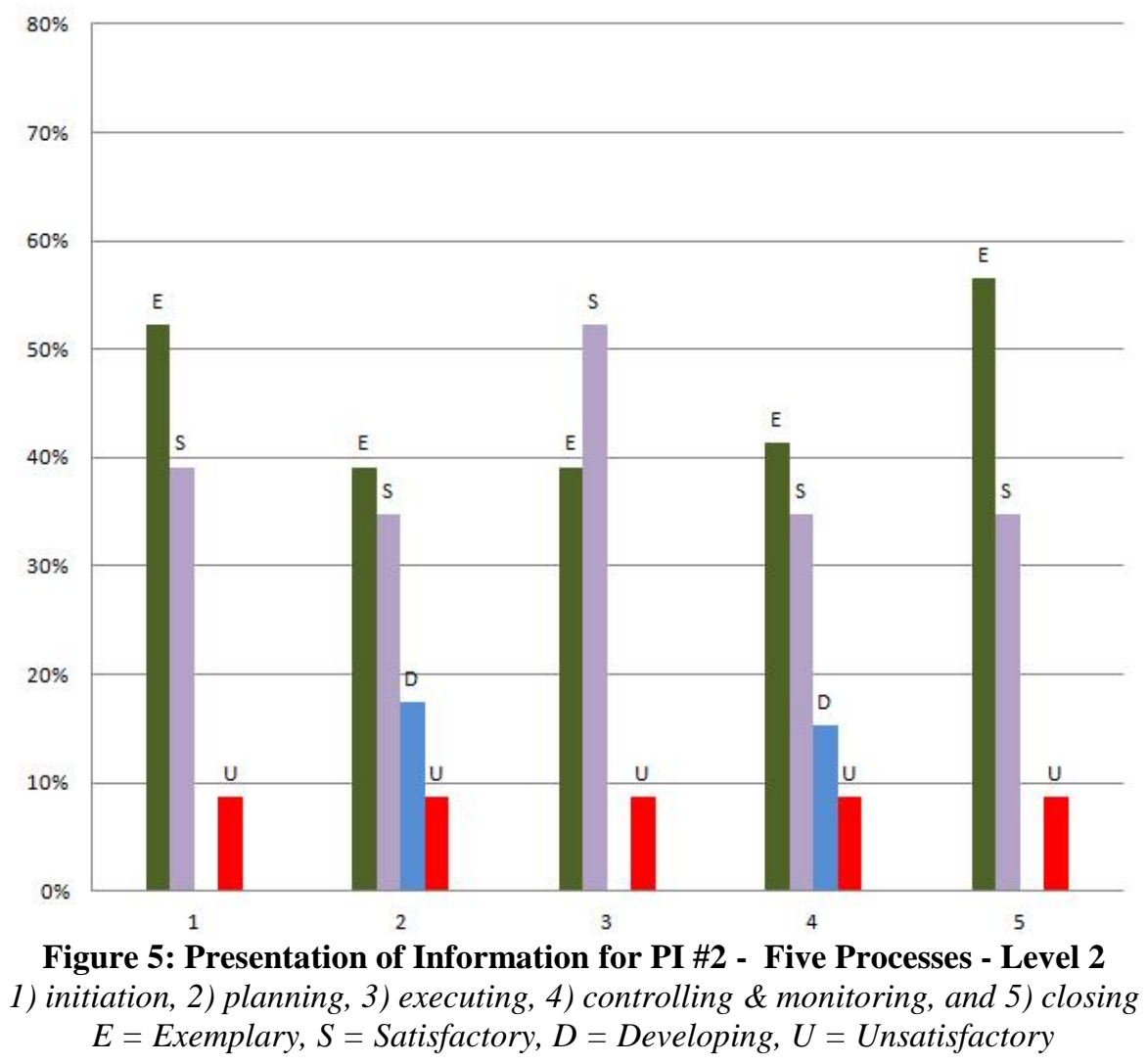

Table 5: The Scores for Level 2 Presentation of Information

\begin{tabular}{|l|r|r|r|r|r|}
\hline & 1 & 2 & 3 & 4 & 5 \\
\hline Exemplary & $52 \%$ & $39 \%$ & $39 \%$ & $41 \%$ & $57 \%$ \\
\hline Satisfactory & $39 \%$ & $35 \%$ & $52 \%$ & $35 \%$ & $35 \%$ \\
\hline Developing & $0 \%$ & $17 \%$ & $0 \%$ & $15 \%$ & $0 \%$ \\
\hline Unsatisfactory & $9 \%$ & $9 \%$ & $9 \%$ & $9 \%$ & $9 \%$ \\
\hline
\end{tabular}

1) initiation, 2) planning, 3) executing, 4) controlling \& monitoring, and 5) closing

As can be seen in Table 5, in the project management process of planning, students scored $74 \%$ (satisfactory $=35 \%$ and exemplary $=39 \%$ ). This project management process did not quite meet the target performance of $80 \%$, therefore, improvement is needed. Looking at the developing score of $17 \%$ in this project management process, one can clearly see that measures ought to be taken to advance the unsatisfactory area to the developing area and the developing area to the satisfactory and/or the exemplary areas. Likewise, looking at the information for project management process of controlling \& monitoring, measures ought to be taken to advance the unsatisfactory area to the developing area and the developing area to the satisfactory and/or the exemplary areas. 


\section{Issues in Information Systems}

Volume 13, Issue 2, pp. 1-10, 2012

\section{Recommended Actions}

The recommended actions for improvement for the student outcome "Use appropriate PM methods in the creation of an effective IT project plan" were determined by the faculty members. For this student outcome, it was recommended that faculty give special attention to the knowledge areas and project management processes that did not meet the target for performance for both performance indicators, specifically cost, communication, planning, and monitoring and controlling. This special attention should be focused on 1) the course designated as source of assessment (ITEC 3300) and 2) the supporting courses (ITEC 3155 \& ITEC 4750 - See Strategies in Table 1) that are designed to provide opportunities for students to learn, practice, demonstrate and/or get feedback on their performance for the performance indicators of this student outcome.

It was also recommended that faculty should review the scoring rubric with students so they can see the expectations for their performance. The faculty will engage in designing possible alternative delivery methods that might improve student learning in the project management knowledge areas and the project management process that require improvement. Additionally, on-line resources will be explored to assist students with their performance in the areas of concern.

\section{CONCLUSION}

This paper presented a systematic process to direct assessment of student outcomes. The process for direct assessment of each student outcome included defining high-level performance indicators; determining strategies; establishing source of assessment; deciding target for performance; creating assessment instrument, constructing the rubric, and collecting data.

The process focuses on information, not data, to make decisions for continuous improvement of the program. The process has shown to provide the faculty with the rich information necessary to make significant and meaningful changes to the curriculum targeted at achieving the desired outcomes. Collecting evidence in systematic and targeted fashion has enabled all faculty to focus on preparing students to achieve the desired outcomes.

This process has provided the faculty to test the new assessment process themselves and to see how the changes were reflected in student learning. By looking at the results of the direct assessment of student outcomes, the faculty can see that student learning is developmental over time and how well the program is achieving the intended outcomes.

\section{REFERENCES}

1. ABET, Inc. (2012). Criteria for Accrediting Computing Programs 2012 - 2013. Retrieved March 2, 2012 from http://abet.org/computing-criteria-2012-2013

2. Rogers, G. (2006). Direct and Indirect Assessment. Assessment 101: Assessment Tips with Gloria Rogers. Retrieved March 2, 2012 from http://www.abet.org/WorkArea/DownloadAsset.aspx?id=1303

3. Rogers, G. (2010). What is Performance Indicator Anyway? Retrieved March 1, 2012 from http://programassessment.blogspot.com/2010/05/what-is-performance-indicator-anyway.html

4. Rogers, G. (2010). Developing Rubrics. ABET Webinar. Retrieved March 3, 2012 from http://www.abet.org/uploadedFiles/Events/Webinars/Developing_Rubrics.pdf 